\title{
A review on dump slope stabilization by revegetation with reference to indigenous plant
}

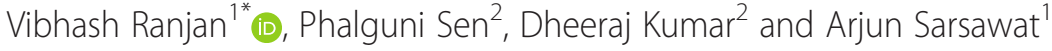

\begin{abstract}
The waste, subgrade ROM and fine dumps of iron ore mines are characterized by high rock fragment contents, low moisture retention capacity, higher bulk density, low nutrients, lower $\mathrm{pH}$ and elevated metal concentrations. Use of suitable revegetation programme, that require the selection of right type of plants to be used vis-à-vis the site condition and characteristics, can enhance the long-term stability, both mechanical and ecological, of dumps (waste, subgrade ROM and fines) through providing vegetative cover to control soil erosion and gully formation, consolidation of dump top and side surfaces, binding the loose particles through intricate roof system, etc. This paper overviews the roles of revegetation programme that can be used where vegetation is considered to be the long-term answer to slope protection and erosion control. Various revegetation processes like Coir matting, lemon grass, vetiver grass and indigenous plant may find a wide range of usage in iron ore mines for dump stabilization. The Miyawaki method of plantation is more effective than the conventional method of plantation. This will lead to co-existence of plants, and as a matter of fact each plant draws from the other vital nutrients and they grow to become strong and healthy. The Miyawaki plantation technique aims at "survival of the fittest", and the area which undergone such plantation has an ecology of their own. The indigenous plant has good binding capacity and helps to control soil erosion as well as improve the dump stability. These indigenous plant species include Shorea robusta (Sal), Dalbergia sisoo (Shisham), Karanj and Azadirachta (Neem). The growth of indigenous plants is dependent upon the soil quality as well as the organic matter of the dump material. The leaf debris plays an important role for improving the organic matter of the dump material to successfully implement the revegetation programme.
\end{abstract}

Keywords: Revegetation, Coir mat, Vetiver grass, Lemon grass, Indigenous plant, Selection of plant species

\section{Review}

Introduction

Opencast mining operations involve huge quantities of overburden \& subgrade ROM removal as well as dumping and backfilling of excavated area. A substantial increase in the rate of accumulation of waste/subgrade ROM materials in recent years has resulted in a greater height of dumps to minimize ground cover area. Consequently, it has given rise to the danger of dump failures, gully erosion and various associated environmental problems (Campbell 1992).

Extraction of valuable minerals has been producing wastes in the form of waste rocks whose management is

\footnotetext{
*Correspondence: vibhash.ranjan@sardamines.net

${ }^{1}$ Thakurani Iron Ore Mines of M/s Sarda Mines (P) Limited, Soyabali, Barbil, Keonjhar, Odisha, India

Full list of author information is available at the end of the article
}

again of prime importance. The issues relating to the stability of these dumps/stacks are catching attention worldwide for quite some time now, which is quite important for the safe working in and around these monstrous structures as well as restricted availability of land. Even government bodies like State Pollution Control Board, Ministry of Environment and Forests and Department of Mines and Geology etc. have raised their concern by way of specified rules and regulations making it mandatory for all mines. Figures 1, 2 and 3 show the critical failure of different types of dump in iron ore mines of Odisha state.

Revegetation is one of the widely used technique for controlling erosion and stabilization of dump slope (Akers and Muter 1974) and thereby maintaining ecological equilibrium in the area (Jorgensen 1994). With respect to the role of vegetation growth upon dump

\section{穴 Springer}




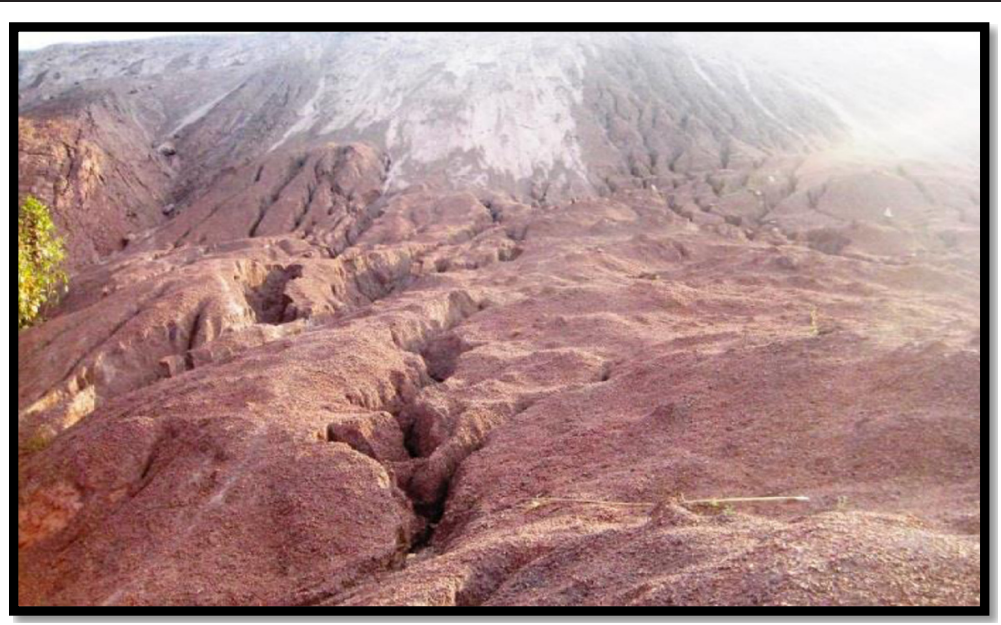

Fig. 1 Slope failure in a subgrade dump of iron ore mines

slope, it can be described as hydrogeological and mechanical actions (Cherubini and Geiasi 1997); with respect to the hydrogeological action, roots of vegetation play an important role to enhance dump stability by controlling interception of rain water and evapotranspiration and the resulting pore pressure reduction (Hussain 1995), whereas mechanical action, in turn, reinforced the dump material by roots and enhanced the shear strength of the dump material. This action is closely related to root density, depth and strength (Greenway 1987; Jha 1989; Suyama 1992; Hall et al. 1994). The indigenous plants like Shorea robusta (Sal), Dalbergia sisoo (Shisham), Karanj and Azadirachta (Neem) have a good binding capacity and help to control soil erosion as well as improve the dump stability. Four species (Karanj, Pongamia sp.; Shisham, Dalbergia sp.; Shirish, Albizia sp.; and Neem, Azadirachta sp.) have emerged as having the highest frequency of reporting in addition to an array of shared and relevant agro- and socioeconomically relevant properties along with notably similar environmental outcomes regarding their impact toward above- and belowground ecological factors. These characteristics include that three (members of the Fabaceae) are promoters of nitrogen-fixing interactions, while all four are relatively fast growers, well adapted to environmental conditions within more arid zones (i.e. intense heat, sunlight) and have root architectural adaptations for drought tolerance (Koul et al. 1990; Lowry et al. 1994; Tewari 1994). The effectiveness of revegetation can be measured through numerical modelling in terms of a factor of safety before and after implementation of the revegetation programme.

\section{Revegetation process and restoration techniques}

Revegetation process is one of the important methods which can make the ecologically challenging task of

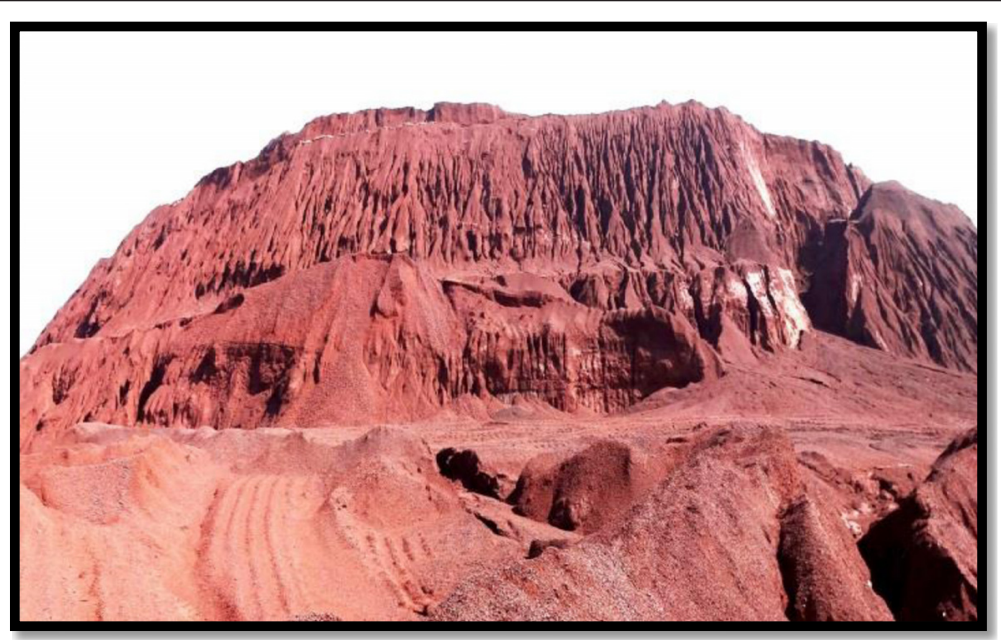

Fig. 2 Slope failure in a fine dump of iron ore mines 


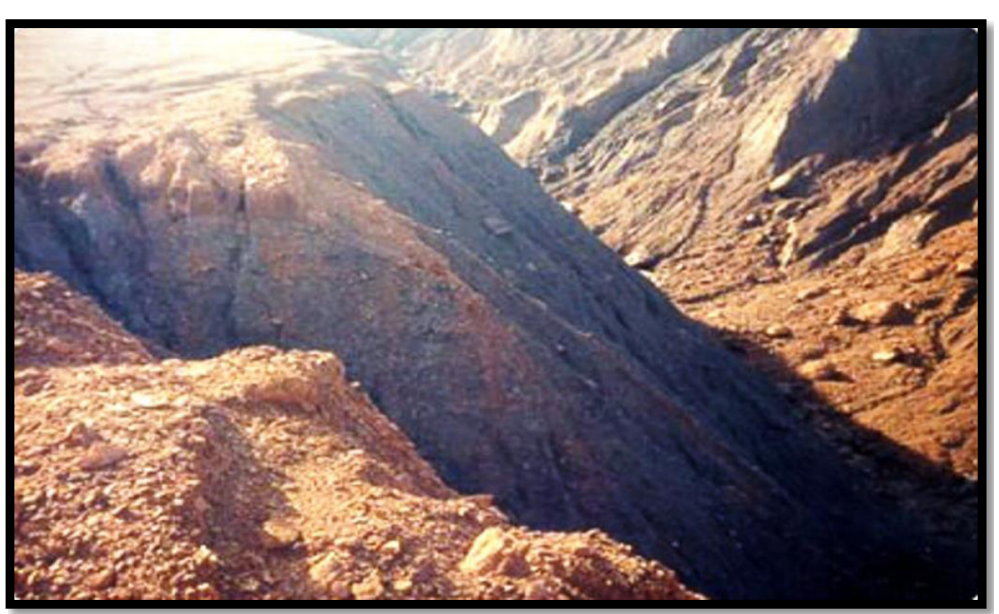

Fig. 3 Slope failure in a waste dump of iron ore mines

restoring the previously existing ecosystem. Revegetation is normally implemented during the monsoon or winter seasons. Plant materials that are adaptive to the site conditions are selected. Local species are readily available and well suited to the climate, soil condition and available moisture; therefore, they make good candidates. The indigenous species like S. robusta (Sal), D. sisoo (Shisham), Karanj and Azadirachta (Neem) have a good binding capacity and help to control soil erosion as well as improve the dump stability.

The evolution of mine revegetation practices has seen the agronomic engineering approach of establishing "green" landscapes with introduced grass and pasture species (Dahl and Mulligan 1996) replaced by the reestablishment of native flora to create a self-sustaining ecosystem. An early attempt to revegetate mined areas at Weipa and Rum Jungle relied on introduced grass and tree species and nitrogen-fixing shrubs (Dahl and Mulligan 1996, Richards et al. 1996).

\section{Coir matting}

Coir mats and netting are dense, biodegradable fabrics made of coconut husk fiber (coir). They are used to trap sediment, to protect stream banks and wetland shores from erosion and to provide a stable substrate for plant establishment. Coir mat is a kind of natural erosion control blanket (Figs. 4 and 5).

\section{Case references of coal mines}

Erosion control blankets like coir mats have been used for slope protection at many places especially in coal mines. Coir mats have also been used to protect high overburden dumps of fly ash, and it has been possible to establish vegetation over the dump. An interesting case

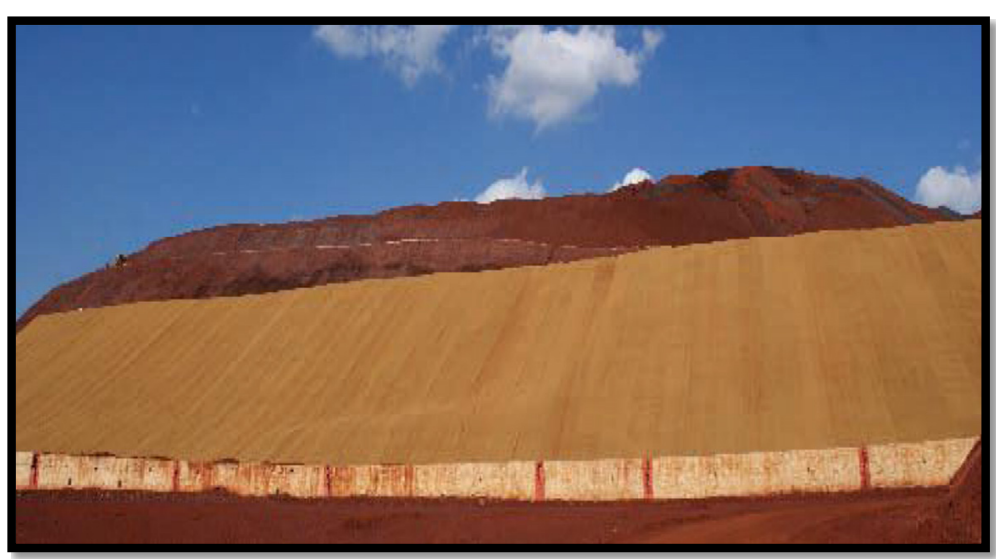

Fig. 4 Installation of coir mat in iron ore mines 


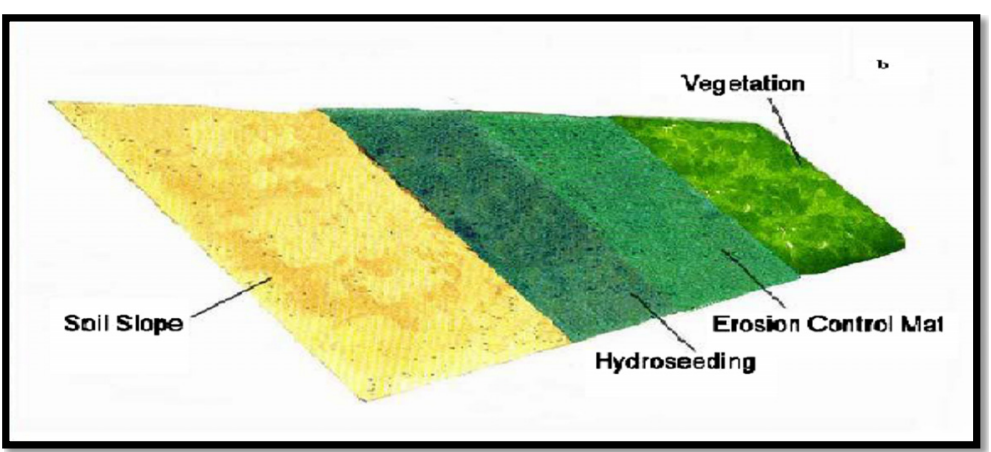

Fig. 5 Coir matting process

study where the effectiveness of gabions and coir mat has been successfully implemented is the stabilization of overburden dumps at coal mines of Singrauli. A huge dump of $120 \mathrm{~m}$ high could be stabilized by a combination of gabion walls and coir mats on slopes. Of course, an in-depth study of strata along with stability analysis combined with quality work at site, all in collection, has contributed to the success of the project.

\section{Disadvantage}

It is not fully successfully implemented in the iron ore mines of Odisha state due to the following reasons.

a. Poor binding properties with the different size of dump materials.

b. It requires a huge quantity of water during the seeding process till plantation.

c. Not a suitable option for large and steep slope of a dump area.

d. There is no use of end product.

e. Poor stabilizing qualities rather than indigenous plant.

f. Poor stabilization of failure surface during heavy rain and wind due to its poor binding properties.

(Figure 6 shows the typical failure of coir matting in the iron ore mines of Odisha).

\section{Vetiver grass}

The indigenous knowledge was taken along when Indians migrated overseas and usage resumed in new localities around the globe. Thus one reads of vetiver usage for slope protection and reinforcement of embankments and cuttings outside of farmlands since the early 1900s in the West Indies, South Africa (National Research Council 1993), Brazil (Grimshaw, 1994) and Fiji (Truoung and Gawander 1996), etc. In 1931, it was on record that vetiver was grown at Serdang (near Kuala Lumpur), Malaysia, where "it is used for holding up steep banks. It is well known to be good for this purpose" (World Bank 1995). These applications of vetiver, however, were based on past experiences that showed them to be effective but without any quantitative engineering data to back them up. To lend technical credence to its introduction, researches have been conducting on the roles of vegetation in relation to slope stability, in particular on tree roots in which the main factors are contributing to slope stabilization (Greenway 1987; Coppin and Richards 1990; Gray 1994).

Vetiver Grass Technology (VGT; Fig. 7 shows the root system of vetiver grass) was first developed for soil and water conservation in farmlands. While this application still plays a vital role in agricultural lands, vetiver grass's unique morphological, physiological and ecological characteristics

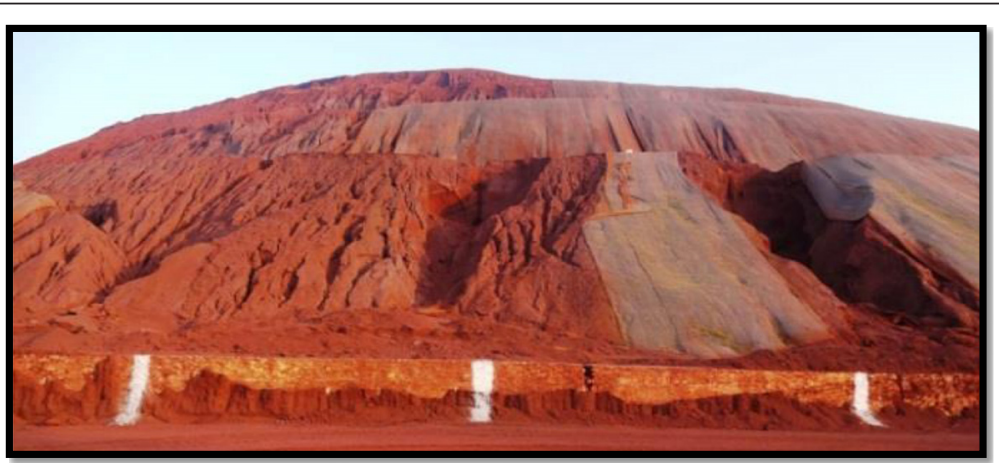

Fig. 6 Photograph of typical failure of coir matting in the iron ore mines of Odisha state 


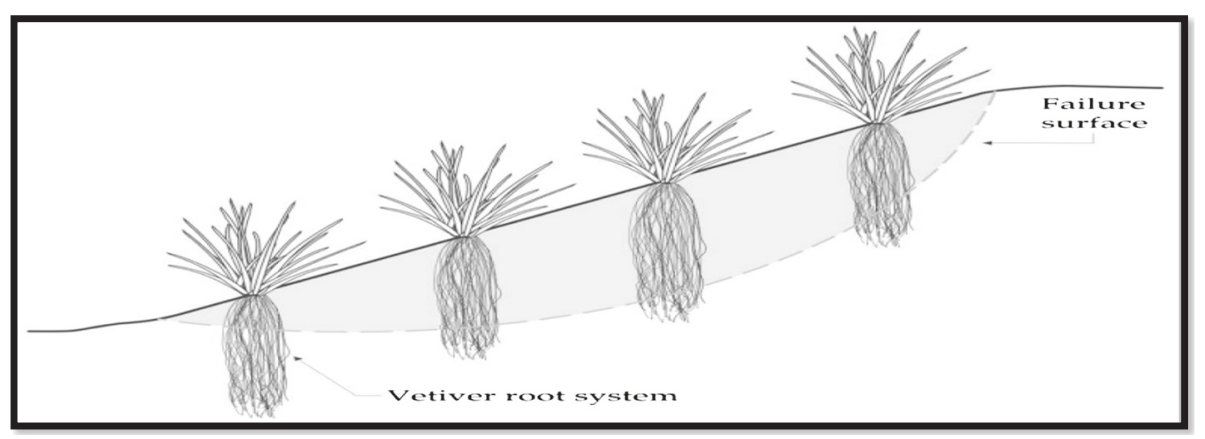

Fig. 7 Root system of vetiver grass

have a key role in the area of environmental protection. Unique morphological characteristics include a massive, finely structured, deep root system capable of reaching 1.2 to $1.5 \mathrm{~m}$.

The Vetiver Grass Technology (VGT), in its most common form, is simply the establishment of an arrow (less than $1 \mathrm{~m}$ wide) live stiff vetiver grass barrier, in the form of a hedge, across the slope of the land. When applied correctly, the technology is effective on slopes from less than 1 to over $100 \%$. In addition, its massive root system will increase the shear strength of soil (thus providing improved stability of soils on steep slopes). Vetiver grass is a clump grass, with erect and stiff stems that grow to as much as $1.2 \mathrm{~m}$ high.

\section{Disadvantage}

a. Seeds easily spread in the wind-may become a weed, infesting an area.

b. Unpalatable to livestock (unsuitable fodder).

c. Not suitable for human consumption.

d. The root of vetiver grass is growing vertically not in a radial direction.

e. Oil extraction is an unlikely option for poor farmers as an end product.

f. Lower stabilizing qualities compared with indigenous trees.

g. Poor stabilization of failure surface due to its vertical roots.

\section{Lemon grass}

An aromatic grass species has indicated that lemon grass can be considered as one of the options for the slope stabilization and control of soil erosion. Lemon grass is one of the species that one can be used for commercial production. It is a tropical grass type originally from India. It derives its name from its strong fresh lemon scent. It is a tufted perennial grass with numerous stiff leafy stems arising from short rhizomatous roots. The leaves can grow up to a height of $2 \mathrm{~m}$. It is a perennial crop and has an economic lifespan of about 5 years. The plant grows on a wide range of soils. The best yields will be obtained from well drained sandy to loam soils, with a $\mathrm{pH}$ value ranging from 4.3 to 8.4 , and with access to water throughout the year, it can give three to four harvests. Often the grass is grown on poor soils or erosionsensitive areas. Without water, it will, through its deep rooting system, survive until the next raining season. The root of lemon grass is in uniaxial direction rather than vertical. It has been not implemented in the dump slope area of iron ore mines. Figure 8 shows the implementation of lemon grass in Herbal Park.

\section{Disadvantage}

a. Seeds easily spread in the wind-may become a weed, infesting an area.

b. It is most suitable in a soil-contained material.

c. It requires a huge quantity of water during the plantation.

d. Not a suitable option for small holdings of hilly areas.

e. Lower stabilizing qualities compared with indigenous plant.

f. Poor stabilization of failure surface due to its binding properties.

g. It is most prone to fire during dry season.

The roots of smaller plants (such as grasses and shrubs) do not go deep, and therefore, the overall effect of grass on dump slope is negligible. However, they stabilize the slope by binding the upper layer of the dump slope. It is observed that the small plants do not significantly improve the factor of safety (FOS) of the slope. However, it could be useful for early stabilization. The grasses quickly bind the upper surface, whereas shrubs immensely strengthen the stability of the dump in the initial stage. Further, it was concluded that the 


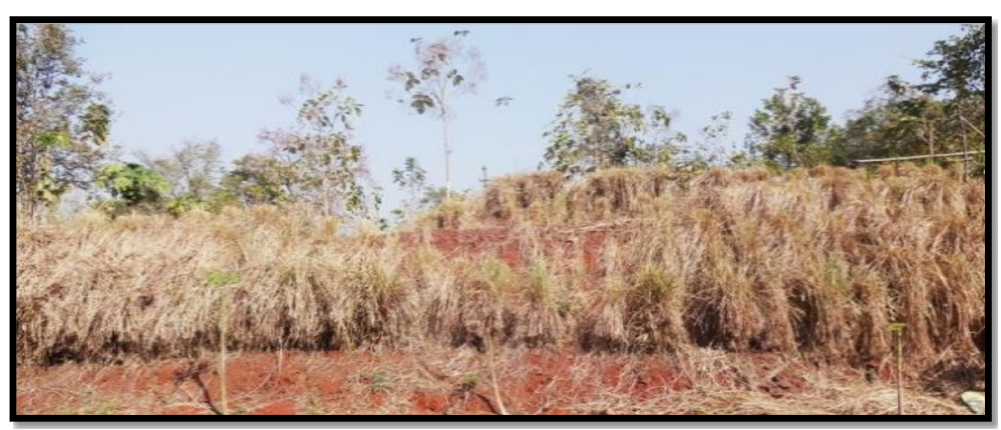

Fig. 8 Implementation of lemon grass in Herbal Park

trees like Shisham (a group of indigenous plant) are used for long-term stability as the roots of trees are stronger and penetrate deeper. Their roots bind the dump material and form a composite material having high shear strength. The Shisham tree of even moderate size binds the upper layers of the mine dump and improves the factor of safety substantially. It was also observed that the stability of the dump slope improves with respect to time, i.e. size of the tree, which is shown in Table 1 (Rai and Shrivastava 2011, 2014).

\section{Miyawaki method of plantation}

The Miyawaki method of plantation is more effective than the conventional method of plantation. The Miyawaki method of planting trees involves the planting of a number of different indigenous plants close together in a small pit or dump slope. By close planting, many random trees close together in a small area enrich the green cover and reinforce the richness of the land. This will lead to coexistence of plants, and as a matter of fact, each plant draws from the other vital nutrients and they grow to become strong and healthy. The Miyawaki plantation technique aims at "survival of the fittest". The area which undergone such plantation has an ecology of their own. Figure 9 shows the successional stages in the Miyawaki methods.

This technique is formulated by Dr. Akira Miyawaki, a Japanese botanist. The technique involves plantation of up to 30 times more trees planted and carbon dioxide absorption, as compared to conventional plantation techniques. There are at least $300 \%$ more species in the

Table 1 Improvement in factor of safety with different ages of tree

\begin{tabular}{lll}
\hline S. No. & Age of tree (Shisham) & Factor of safety \\
\hline 1 & Without vegetation & 1.25 \\
2 & 1 year & 1.26 \\
3 & Two and half years & 1.31 \\
4 & 4 years & 1.46 \\
5 & 5 years & 1.58 \\
\hline
\end{tabular}

same area as compared to conventional plantation species. There is a $3000 \%$ increase in noise and dust isolation with growth of at least $1 \mathrm{~m}$ every year, in tree height.

The potential natural vegetation indicates the potential capacity of the land, theoretically considered, as to which vegetation it can sustain (Miyawaki 1992). Tree species must be chosen from the forest communities of the region in order to restore multilayer natural or quasinatural forests. The Miyawaki method of reconstitution of "indigenous forests by indigenous trees" produces a rich, dense and efficient protective pioneer forest in 4 to 6 years.

\section{Advantages}

1. A completely maintenance free, successful plantation after 3 years.

2. A completely chemical-fertilizer free plantation that sustains itself and supports local biodiversity.

A field trail has been taken in the Thakurani Iron Ore Mines, Block-B of M/s Sarda Mines (P) Limited in the year of 2011 under the guidance and presence of Sri V. P. Upadhyay, Director(S), Ministry of Environment and Forest. Figures 10 and 11 show the implementation of the Miyawaki methods.

\section{Revegetation as a stabilizing agent on dump slopes}

There is a generalized agreement that "forest plays an important role in the protection of soil, and deforestation can bring about not only erosion but also collective soil movements" (Gray 1973). Sternberg (1975) mentions studies by Bailey, who by measuring the maximum angle of the repose of slopes with and without vegetation, found that in a given soil derived from the same rock pattern, the maximum angle of repose is about $60^{\circ}$ when vegetation exists and about $36^{\circ}$ in the case of a lack of vegetation. Vegetation has an important role in protecting the soil surface from erosion and allowing accumulation of fine particles (Tordoff et al. 2000; Conesa et al. 2007b). They can reverse the 


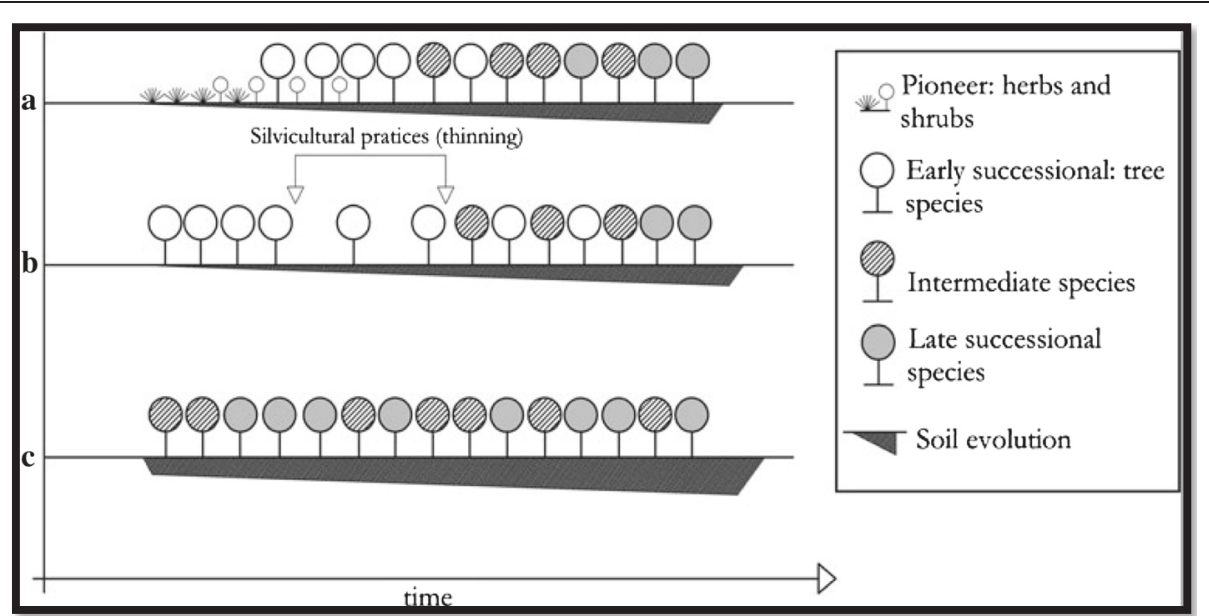

Fig. 9 Successional stages as would follow in natural conditions. a, b Adopting traditional reforestation methods and (c) the Miyawaki method

degradation process by stabilizing soils through the development of extensive root systems. Once they are established, plants increase soil organic matter, lower soil bulk density and moderate soil $\mathrm{pH}$ and bring mineral nutrients to the surface and accumulate them in available form. Their root systems allow them to act as scavengers of nutrients not readily available. The plants accumulate these nutrients and redeposit them on the soil surface in organic matter from which nutrients are much more readily available by microbial breakdown (Li 2006; Conesa et al. 2007a).

The revegetation of eroded ecosystems must be carried out with plants selected on the basis of their ability to survive and regenerate or reproduce under severe conditions provided both by the nature of the dump material, the exposed situation on the dump surface and on their ability to stabilize the soil structure (Madejon et al. 2006). Normal practice for revegetation is to choose drought-resistant, fast growing crops or fodder which can grow in nutrient-deficient soils. Selected plants should be easy to establish, grow quickly and have dense canopies and root systems. In certain areas, the main factor in preventing vegetation is acidity. Plants must be tolerant of metal contaminants in such sites (Caravaca et al. 2002; Mendez and Maier 2008).

A role of exotic or native species in reclamation needs careful consideration as newly introduced exotic species may become pests in other situations. Therefore, candidate species for vegetation should be screened carefully to avoid becoming problematic weeds in relation to local to regional floristic. For artificial introduction, selection of species that are well adapted to the local environment should be emphasized. Indigenous species are preferable to exotics because they are most likely to fit into a fully functional ecosystem and are climatically adapted (Chaney et al. 2007).

Grasses are considered as a nurse crop for an early vegetation purpose. Grasses have both positive and negative effects on mine lands. They are frequently needed to

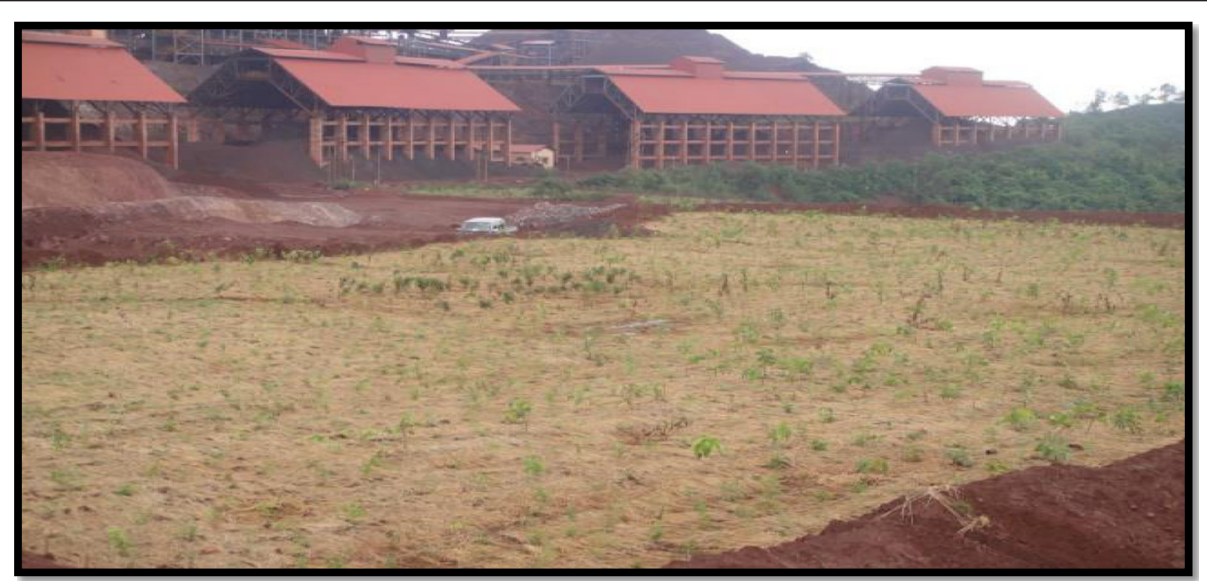

Fig. 10 Plantation by Miyawaki method during 2012 


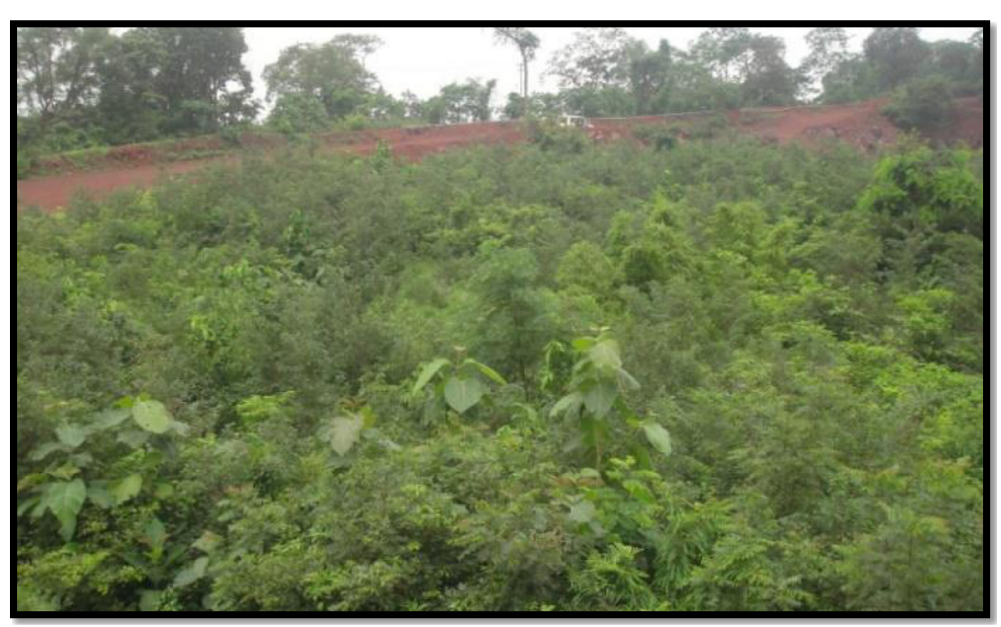

Fig 11. Growth of Miyawaki plantation during 2013

stabilize soils but they may compete with woody regeneration. Grasses can offer superior tolerance to drought, low soil nutrients and other climatic stresses. Roots of grasses are fibrous that can slow erosion, and their soilforming tendencies eventually produce a layer of organic soil, stabilize soil, conserve soil moisture and may compete with weedy species. The initial cover must allow the development of diverse self-sustaining plant communities (Shu et al. 2002; Singh et al. 2002; Hao et al. 2004).

Trees can potentially improve soils through numerous processes, including maintenance or increase of soil organic matter, biological nitrogen fixation, uptake of nutrients from below and reach of roots of under storey herbaceous vegetation, increase water infiltration and storage, reduce loss of nutrients by erosion and leaching, improve soil physical properties, reduce soil acidity and improve soil biological activity. Also, new self-sustaining top soils are created by trees. Plant litter and root exudates provide nutrient cycling to soil (Pulford and Watson 2003; Padmavathiamma and Li 2007).

On mine spoils, nitrogen is a major limiting nutrient, and regular addition of fertilizer nitrogen may be required to maintain healthy growth and persistence of vegetation (Yang et al. 2003; Singh et al. 2004). An alternative approach might be to introduce legumes and other nitrogen-fixing species. Nitrogen-fixing species have a dramatic effect on soil fertility through production of readily decomposable nutrient-rich litter and turnover of fine roots and nodules. Mineralization of N-rich litter from these species allows substantial transfer to companion species and subsequent cycling, thus enabling the development of a self-sustaining ecosystem (Zhang et al. 2001). Singh et al. (2002) reported that native leguminous species show greater improvement in soil fertility parameters in comparison to native non-leguminous species.

\section{Selection of plant species-a vital component for ecorestoration success}

The choice of plant species depends on the characteristics of spoil, climatic condition and ultimate land use. Indigenous plants such as Sal, Kendu, Amla, Jamun, Shisham, Croton roxburghii, Karanj and Neem are more tolerant to adverse spoil $\mathrm{pH}$ and moisture stress than grass and legumes and are therefore, easier to establish. This indigenous plants are used where a wind break is desired, or where a visual shield is required, they are suitable to steep or rocky terrain and coarse waste. The successful vegetation establishment of waste dumps also depends on micro- and macro-climate, disease and insect resistance, competition, growth pattern and propagation ability of the species. The availability of moisture in the spoil, especially during warm dry summer, is important. If the water level is not high enough, irrigation may be necessary to provide moisture. As the vegetation matures, the need for the irrigation diminishes since indigenous plant gets adapted to dry summer condition.

In spite of the relatively modest peer-review literature pool available on the topic of post-mined land revegetation in India, there is still a remarkably extensive reporting of plant species $(n=245 \mathrm{sp}$.) including vegetative growth forms and diverse bio-indicators of ecological form and function. With this rationale, four species (Karanj, Pongamia sp.; Shisham, Dalbergia sp.; Shirish, Albizia sp.; and Neem, Azadirachta sp.) have emerged as having the highest frequency of reporting in addition to an array of shared and relevant agro- and socioeconomically relevant properties along with notably similar environmental outcomes regarding their impact toward above- and belowground ecological factors. These characteristics include that three (Karanj, Pongamia sp.; Shisham, Dalbergia sp.; Shirish, Albizia sp members of the Fabaceae) are promoters of nitrogen-fixing 
interactions, while all four are relatively fast growers, well adapted to environmental conditions within more arid zones (i.e. intense heat, sunlight) and have root architectural adaptations for drought tolerance (Koul et al. 1990; Lowry et al. 1994; Tewari 1994). The growth of indigenous plants is dependent upon the soil quality as well as the organic matter of the dump material. The leaf debris plays an important role for improving the organic matter of the dump material for the successful implementation of revegetation.

\section{Factors affecting for selection of species for revegetation}

According to Morgan (2005), species to be used for revegetation should be selected based on the following parameters: species properties of rapid growth; toughness in respect of diseases and pests; ability to compete with less desirable species; adaptability to the local soil and adaptability to the local climatic conditions.

When the species to be used in the revegetation programmes are trees, they should possess the following qualities, according to Young (1997), for it to be qualified for use in soil fertility improvement/restoration: primarily have the capacity to grow on poor soils; high rate of nitrogen fixation; high and balanced nutrient content in foliage litter; litter low in lignin and polypherols; either rapid litter decay where nutrient release is desired or moderate rate of litter decay where soil cover is required; absence of toxic substances in litter or root residues; well-developed tap root system; high rate of leafy biomass production and a dense network of fine roots with a capacity for mycorrhizal association.

Species selection will depend on local soil and climatic conditions but should aim to provide a uniform rather than clumpy pattern of vegetation to avoid concentrations of runoffs and localized erosion. The ideal condition is difficult to achieve, however, where the soils have low water retention capacity or are toxic, or where cold, drought or exposure inhibits plant growth. Choosing vegetation which has beneficial effect is important (Morgan 2005). For instance, in order to reduce the cost of reclamation of mine spoil mounds from metal mining on the Jos Plateau, Nigeria, the mine lands reclamation unit chose Eucalyptus sp. which could be cropped as a source of fuel and pole timber, but these have resulted in significant declines in the $\mathrm{pH}$ of the soil (Alexander 1990) to the detriment of other plant growth (Morgan 2005).

The revegetation of eroded ecosystems must be carried out with plants selected on the basis of their ability to survive and regenerate or reproduce under severe conditions provided both by the nature of the dump material, the exposed situation on the dump surface and on their ability to stabilize the soil structure (Madejon et al.
2006). Normal practice for revegetation is to choose drought-resistant, fast growing crops or fodder which can grow in nutrient-deficient soils. Selected plants should be easy to establish, grow quickly and have dense canopies and root systems. In certain areas, the main factor in preventing vegetation is acidity (Sheoran et al. 2010). Plants must be tolerant of metal contaminants in such sites (Caravaca et al. 2002; Mendez and Maier 2008).

\section{Conclusions}

For centuries, indigenous living plants were the only material for hill and slope stabilization works. With advancing technology, this age-old concept has been further refined, and some innovative techniques are being adopted. Revegetation is the most appropriate for environmentally and aesthetically sensitive areas. Various ecological restoration approaches like coir matting, lemon grass, vetiver grass and indigenous plant may find a wide range of usage in iron ore mines for different types of dump slope stabilization. The roots of smaller plants (such as grasses and shrubs) do not go deep; therefore, the overall effect of grass on dump slope is negligible. However, they stabilize the slope by binding the upper layer of the dump slope. It is observed that the small plants do not significantly improve the factor of safety (FOS) of the dump slope. However, it could be useful for early stabilization. The grasses quickly bind the upper surface, whereas shrubs immensely strengthen the stability of the dump in the initial stage. Further, it was concluded that the trees like Shisham (a group of indigenous plant) are used for long-term stability as the roots of trees are stronger and penetrate deeper. Their roots bind the dump material and form a composite material having high shear strength. The Shisham tree of even moderate size binds the upper layers of mine dump and improves the factor of safety substantially (which has been shown in Table 1).

A further study regarding the experimental trail is required in respect to the different types of dump slope stabilization in iron ore mines with reference to indigenous plant. Indigenous plant is a native typical dry deciduous forest dominated by tree species $S$. robusta (Sal), D. sisoo (Shisham), Karanj, Azadirachta (Neem) etc. has a good binding capacity and helps to control soil erosion as well as improves the dump stability. In fact, vegetation helps dissipate the kinetic energy of rain drops, attenuates the effects of wind and helps reduce the velocity of overland flow. The most critical aspect of revegetation intervention is the choice of plants and vegetation. But the problem needs to be properly analysed, and the technically best possible solution needs to be adapted without any compromise to safety of the structure and surroundings. In order to get a complete 
advantage of the environmental friendly solution, it is best to select the indigenous plants with the help of a horticulturist after studying the area, its climatic conditions, humidity range, soil type, annual rainfall and other relevant criteria.

\section{Competing interests}

The authors declare that they have no competing interests.

\section{Authors' contributions}

All authors contributed significantly to this work. PS and DK designed the overall framework of this paper. VR conducted a thorough review of the literature and developed the manuscript as well as the overall manuscript. AS contributed regarding slope stabilization-related information. All authors read and approved the final manuscript.

\section{Acknowledgements}

Thanks to the Sri Arjun Sarsawat for giving me the opportunity to using the past implementation work related to slope dump stabilization and also provide the guidance to study about indigenous plant in horticulture department of the iron ore mines.

\section{Author details}

${ }^{1}$ Thakurani Iron Ore Mines of M/s Sarda Mines (P) Limited, Soyabali, Barbil, Keonjhar, Odisha, India. ${ }^{2}$ Department of Mining Engineering, Indian School of Mines, Dhanbad 826004, India.

Received: 5 August 2015 Accepted: 16 October 2015

Published online: 27 October 2015

\section{References}

Akers JD, Muter BR (1974) Gob pile stabilization and reclamation. Proceeding of the Forth Mineral Waste Utilization Symposium, Chicago, Illinois, pp. 229-239.

Alexander MJ (1990) Reclamation after tin mining on the Jos plateau. Nigeria Geographical J 156:44-50

Campbell DB (1992) Resloping of waste rock dumps. Int Mine Waste Manag News 2(2):7-10

Caravaca F, Hernandez MT, Garcia C, Roldan A (2002) Improvement of rhizosphere aggregates stability of afforested semi- arid, plant species subjected to mycorrhizal inoculation and compost addition. Geoderma 108:133-144

Chaney RL, Angle JS, Broadhurst CL, Peters CA, Tappero RV, Donald LS (2007) Improved understanding of hyper accumulation yields commercial phytoextraction and phytomining technologies. J Environ Qual 36:1429-14423

Cherubini C, Geiasi C (1997) The influence of vegetation on slope stability. In: Marinos PG, Koukis GC, Tsiambaos GC, Stournaras GC (eds) Engineering geology and environment, vol I. Balkema, Rotterdam, pp 67-71

Conesa HM, Schulin R, Nowack B (2007a) A laboratory study on revegetation and metal uptake in native plant species from neutral mine tailings. Water Air Soil Pollut 183(1-4):201-212

HM, Garcia G, Faz A, Arnaldos R (2007b) "Dynamics of metal tolerant plant communities" development in mine tailings from the Cartagena-La Union Mining District (SE Spain) and their interest for further revegetation purposes. Chemosphere 68:1180-1185

Coppin NJ, Richards IG (1990) Use of vegetation in civil engineering construction industry and research information association (CIRIA). Butterworths, London

Dahl NW, Mulligan DR (1996) Environmental management at Weipa: Bauxite mining in the tropical north. In: Mulligan DR (ed) Environmental management in the Australian minerals and energy industry: principles and practices. UNSW Press, Sydney, pp 403-420

Gray DH (1973) Effects of forest clear cutting on the stability of natural slopes: results of field studies. National Science Foundation, University of Michigan, Washington

Gray DH (1994) Influence of vegetation on stability of slopes. In: Vegetation and slopes. Institution of Civil Engineers, London, pp 2-25

Greenway DR (1987) Vegetation and slope stability. In: Anderson MG, Richards KS (eds) Slope stability. John Wiley and Sons Ltd, New York
Grimshaw RG (1994) Vetiver grass-its use for slope and structure stabilization under tropical and semitropical conditions. In: Vegetation and slopes. Institution of Civil Engineers, London, pp 26-35

Hall BE, Giles EL, Rauch HP (1994) Experiences with the Use of Trees in Slope Stabilization. In: Proceedings of XIII ICSMFE, New Delhi, pp 1231-1235

Hao XZ, Zhou DM, Wang YJ, Chen HM (2004) Study of rye grass in copper mine tailing treated with peat and chemical fertilizer. Acta Pedol Sin 41(4):645-648

Hussain A (1995) Fill compaction-erosion study in reclaimed areas. Indian Mining Eng J 34(6):19-21

Jha AK (1989) A note on the root development in dry tropical naturally revegetated coal mine spoil. Vegetation 85:67-70

Jorgensen SE (1994) Models as instruments for combination of ecological theory and environmental practice. Ecol Model 75/76:5-20

Koul O, Isman MB, Ketkar CM (1990) Properties and uses of neem, Azadirachto indica. Can J Bot 68:1-11

Li MS (2006) Ecological restoration of mine land with particular reference to the metalliferous mine wasteland in China: a review of research and practice. Soil Total Environ 357:38-53

Lowry JB, Prinsen H, Burrows DM (1994) Albizia lebbeck: a promising forage tree for semiarid regions. In: Gutteridge RC, Shelton HM (eds) Forage tree legumes in tropical agriculture. CAB International, Wallingford, Oxon, UK, pp 75-83

Madejon E, de Mora AP, Felipe E, Burgos P, Cabrera F (2006) Soil amendments reduce trace element solubility in a contaminated soil and allow re-growth of natural vegetation. Environ Pollut 139:40-52

Mendez MO, Maier RM (2008) Phytostabilization of mine tailings in arid and semiarid environments-an emerging remediation technology. Environ Health Perspect 116(3):278-283

Miyawaki A (1992) Restoration of evergreen broadleaved forests in the Pacific region. In: Wali MK (ed) Ecosystem rehabilitation, ecosystem analysis and synthesis, vol 2. SPB Academic Publishing, The Hague, pp 233-245

Morgan RPC (2005) Soil erosion and conservation, vol 59, 3rd edn. Blackwell Publishing Company Ltd, U.K., pp 169-70, 190-91

National Research Council (1993) Vetiver grass: a thin green line against erosion. National Academy Press, Washington DC, USA

Padmavathiamma PK, Li LY (2007) Phytoremediation technology: hyper accumulation metals in plants. Water Air Soil Pollut 184(1-4):105-126

Pulford ID, Watson C (2003) Phytoremediation of heavy metal-contaminated land trees-a review. Environ Int 29:529-540

Rai R, Shrivastava BK (2011) Biological stabilization of mine dumps: shear strength and numerical simulation approach with reference to Sisam tree. Environ Earth Sci 63:177-188

Rai R, Shrivastava BK (2014) Numerical simulation of vegetated mine dump slope with reference to small plants. Int J Min Sci Tech 24(2014):111-115

Richards RJ, Applegate RJ, Richie AIM (1996) The Rum Jungle rehabilitation project. In: Mulligan DR (ed) Environmental management in the Australian minerals and energy industries. UNSW Press \& AMEEF, Sydney, pp 464-553

Sheoran V, Sheoran AS, Poonia P (2010) Soil reclamation of abandoned mine land by revegetation: a review. Int I Soil, Sediment and Water 3:1-21, Available at: http://scholarworks.umass.edu/intljssw/vol3/iss2/13

Shu WS, Xia HP, Zhang ZQ, Wong MH (2002) Use of vetiver and other three grasses for revegetation of $\mathrm{Pb} / \mathrm{Zn}$ mine tailings: field experiment. Int J Phytoremediation 4(1):47-57

Singh AN, Raghubanshi AS, Singh JS (2002) Plantations as a tool for mine spoil restoration. Curr Sci 82(12):1436-1441

Singh AN, Raghubanshi AS, Singh JS (2004) Impact of native tree plantations on mine spoils in a dry tropical environment. For Ecol Manage 187:49-60

Sternberg HO (1975) Effects of deforestation on slopes. J Geotech Eng Div 101:147-165

Suyama M (1992) Assessment of biotechnical slope stability effect for urban forest in Japan. In: Proceedings of 6th International Symposium on Landslides. A Balkema, Christchurch, pp 831-836

Tewari DN (1994) A monograph on Dalbergia sissoo Roxb. International Book Distributors, Dehradun, India

Tordoff GM, Baker AJM, Willis AJ (2000) Current approaches to the revegetation and reclamation of metalliferous mine wastes. Chemosphere 41:219-228 
Truoung P, Gawander JS (1996) Back from the future: do's and don'ts after 50 years of vetiver utilization in Fiji. In: Proceedings of the First International Conference on Vetiver. Office of the Royal Development Projects Board, Bangkok, pp 12-17

Yang B, Shu WS, Ye ZH, Lan CY, Wong MH (2003) Growth and metal accumulation in vetiver and two Sesbania species on lead/zinc mine tailings. Chemosphere 52(9):1593-1600

Young A (1997) Agroforestry for soil management, effects of trees on soils, vol 23. CAB International, Wallingford, UK

Zhang ZQ, Shu WS, Lan CY, Wong MH (2001) Soil seed bank as an input of seed sources in vegetation of lead/ zinc mine tailings. Restoration Ecol 9(4):1-8

Submit your manuscript to a SpringerOpen ${ }^{\odot}$ journal and benefit from:

- Convenient online submission

- Rigorous peer review

- Immediate publication on acceptance

- Open access: articles freely available online

- High visibility within the field

- Retaining the copyright to your article

Submit your next manuscript at $\gg$ springeropen.com 